\title{
SINTESIS DAN KARAKTERISASI BORNEOL DARI $\alpha$-PINENA GETAH PINUS (Pinus merkusii Jungh. \& de Vriese)
}

\section{(Synthesized and Characterization of Borneol from Pine (Pinus merkusii Jungh. \& de Vriese) Resin's $\alpha$-pinene)}

\author{
Gunawan Pasaribu, Totok K. Waluyo \& Lisna Efiyanti \\ Pusat Penelitian dan Pengembangan Hasil Hutan \\ Jl. Gunung Batu No. 5 Bogor 16610, Telp. (0251) 8633378, Faks. (0251) 8633413 \\ Email : gun_pa1000@yahoo.com
}

Diterima 30 Januari 2019, direvisi 26 Februari 2021, disetujui 15 Juni 2021

\begin{abstract}
Pine resin is obtained from a process of tapping the pine tree (Pinus merkusii Jungh. \& de V riese). After processing, pine resin will produce gondorukem and turpentine. Currently, the utilization of turpentine is mainly for cosmetic, paint, a mixture of solvents, antiseptics, and pharmaceuticals. Due to an increase in the added value of the turpentine product, turpentine was synthesized into borneol. This study aimed to analyze the characteristics of borneol produced from the synthesis of a-pinene using $\mathrm{NaOH}$ and $\mathrm{KOH}$ bases. The method was carried out by synthesized $\alpha$-pinene into borneol through sodium reduction using two alkali e.i $\mathrm{KOH}$ and $\mathrm{NaOH}$. The compounds were characterized by FTIR, NMR and GCMS. The results showed that on FTIR analysis of 12 samples of the borneol synthesized showed fairly similar absorption peaks with peaks appearing on standard borneol FTIRs. The NMR analysis of both HNMR and CNMR, compared with the standard NMR compounds a-pinene, champor and borneol, show that the peaks still show differences. The GCMS result showed the formation of the compound of borneol compound with the percentage of 0.12 to $2.2 \%$ relatives. The type of base and origin of the turpentine used did not show any difference in borneol yield.
\end{abstract}

Keywords: $\alpha$-pinene, borneol, resin, synthesized

\section{ABSTRAK}

Getah pinus diperoleh dari proses penyadapan pohon pinus (Pinus merkusii Jungh. \& de Vriese). Setelah mengalami pengolahan, getah pinus akan menghasilkan produk berupa gondorukem dan terpentin. Pemanfaatan terpentin diantaranya untuk kosmetik, cat, campuran bahan pelarut, antiseptik, dan farmasi. Untuk meningkatkan nilai tambah produk terpentin dilakukan sintesis terpentin menjadi borneol. Penelitian ini bertujuan untuk menganalisis karakteristik borneol yang diperoleh dari sintesis $\alpha$-pinena menggunakan basa $\mathrm{NaOH}$ dan $\mathrm{KOH}$. Metode yang dilakukan yaitu melalui reaksi reduksi logam natrium menggunakan dua jenis basa yaitu $\mathrm{KOH}$ dan $\mathrm{NaOH}$. Senyawa yang diperoleh dikarakterisasi dengan FTIR, NMR, dan GCMS. Hasil penelitian menunjukkan dari analisis FTIR 12 sampel hasil sintesis borneol menunjukkan puncak-puncak absorpsi yang cukup serupa dengan puncak yang muncul pada FTIR standar borneol. Hasil analisis NMR baik itu HNMR dan CNMR, jika dibandingkan dengan standar NMR senyawa $\alpha$-pinena, kamfer, dan borneol, maka dapat dilihat bahwa puncak-puncak serapan masih menunjukkan perbedaan dengan ketiga senyawa tersebut. Hasil GCMS menunjukkan terbentuknya sintesis senyawa borneol dengan persentase 0,12-2,03\%. Jenis basa dan asal terpentin yang digunakan tidak menunjukkan adanya perbedaan kadar borneol.

Kata kunci: $\alpha$-pinena, borneol, resin, sintesis

\section{PENDAHULUAN}

Indonesia memiliki kekayaan akan sumber daya alam, salah satunya adalah yang berasal dari hutan tropis Indonesia, yang menghasilkan produk kayu serta hasil hutan bukan kayu (HHBK). Produk HHBK ini sangat beraneka ragam dan memiliki potensi yang sangat tinggi, diantaranya terpentin sebagai turunan getah pinus. Sebagai negara terbesar ketiga penghasil terpentin, Indonesia memiliki pabrik terpentin Perbutani Pine Chemical Industry (PPIC) yang dikelola Perhutani dengan target 2,2 triliun rupiah pertahun, dan mampu menyumbang $47 \%$ pendapatan Perhutani (Perhutani, 2020). Komponen utama minyak terpentin ialah $\alpha$-pinena yang dapat berfungsi dalam produksi parfum serta prekursor fine chemical (Wu, Wang, Chen, Wei, Liang, dan Yao, 2019). Minyak terpentin Indonesia mengandung sekitar 57$86 \% \alpha$-pinena, $8-12 \% \quad \delta$-cerena dan golongan monoterpena yang lain dengan jumlah minor. Frattini, Isaacs, Farlett, Wilson, Kyriakou, dan Lee, 
(2017) menyebutkan bahwa terpentin merupakan sumber biogenik penting (struktur molekul berasal dari isoprene dengan komponen utama pinena, limonene, champene, dan terpinolene) yang diperoleh dari destilasi resin selama proses mekanis pohon pinus.

Pengolahan turunan minyak terpentin masih sangat minim dilakukan di Indonesia (Wiyono, Tachibana, \& Tinambunan, 2006). Satu-satunya industri pengolahan turunan minyak terpentin di Indonesia adalah Perhutani yang berlokasi di Pemalang sedangkan pengguna terpentin tersebar di berbagai negara diantaranya Jepang, Spanyol, India, Amerika Serikat, Jerman, Inggris, dan Singapura (Daryono, 2015). Pada tahun 2018, Perhutani memproduksi terpentin 14.328 ton dan gondorukem 66.845 ton. Pemasaran gondorukem di dalam negeri mencapai 4.259 ton dan terpentin sebanyak 2.459 ton, gondorukem dan turunan terpentin sebanyak 1.317 ton, sedangkan penjualan gondorukem ke luar negeri mencapai 62.903 ton dan terpentin 10.040 ton (Perum Perhutani, 2019).

Produk turunan terpentin sangat menunjang kebutuhan industri manufaktur. $\alpha$-pinena ini merupakan monoterpen alami yang umum digunakan sebagai bahan kimia, farmasi, dan pengharum (Kim, Sowndhararajan, Jin, \& Kim, 2018), bahkan kandidat yang baik untuk pengganti bahan bakar jet (Niu, Huang, Ji, \& Liu, 2019; Bao, Zhang, \& Meng, 2019). $\alpha$-pinena juga memiliki kandungan antioksidan dengan nilai EC50 $=310 \pm 10 \mathrm{mg} / \mathrm{mL}$ dan tes FRAP EC50 $=238 \pm 18,92 \mathrm{mg} / \mathrm{mL}$, sehingga $\alpha$-pinena mampu melindungi sel IEC-6 melawan stress oksidatif yang diinduksi aspirin (Bouzenna, Hfaiedh, \& Giroux-metges, 2017).

Ekstraksi $\alpha$-pinena dari terpentin pada umumnya menghasilkan rendemen dan konsentrasi yang sangat kecil, sehingga banyak mekanisme yang dicoba untuk memaksimalkan hasil tersebut, diantaranya menggunakan rekombinasi plasmid, sehingga menghasilkan titer pinene 104,6 mg/L (Bao et al., 2019). Tingkat kemurnian $\alpha$-pinena dapat mempengaruhi nilai jual $\alpha$-pinena tersebut, semakin tinggi kemurniannya akan semakin tinggi nilai jualnya. Selama ini, $\alpha$-pinena mayoritas dijual langsung secara ekspor tanpa diolah lebih lanjut menjadi produk turunannya. Hal ini mengakibatkan harga jual $\alpha-$ pinena tidak terlalu tinggi. Padahal senyawa $\alpha$-pinena ini juga dapat menjadi senyawa utama dalam pembuatan senyawa lain yang lebih bermanfaat dan bernilai tinggi, seperti $\alpha$-terpinoel dan borneol yang dapat berfungsi sebagai senyawa prekursor penting dalam pembuatan obat, kandungan parfum pada kosmetik (Bhatia, Letizia, \& Api, 2008). $\alpha$-pinena juga dapat menghasilkan senyawa lain seperti trans- carveol, trans-sobrerol atau pinol yang merupakan prekursor pengharum dan farmasi melalui reaksi isomerisasi dibantu katalis (Ribeiro et al., 2018). Senyawa-senyawa tersebut merupakan senyawa golongan terpenoid (monoterpen, $\mathrm{C}_{10}$ ). Senyawa yang mempunyai aktivitas anti-inflamasi di tingkat sel, serta berpotensi untuk pencegahan beberapa penyakit terkait penurunan aktivitas sel syaraf. Di samping itu, senyawa ini juga mempunyai aktivitas dalam menghambat pertumbuhan bakteri Staphylococcus aureus dan Eschericia coli (Masruri, Rahman, \& Prasosjo, 2007), komposit borneol dengan graphene oxide juga dilaporkan mampu memberi efek antifungal terhadap M. racemosus (Li, Zhau, Hong, Quan, Yuan, Wang, 2017).

Borneol banyak dimanfaatkan sebagai biomedicine untuk mencegah pengentalan dan pembekuan darah (Duke, 2005), bahkan borneol alam dapat bertindak sebagai chemosensitizer bersama dengan doxorubisin, sehingga menjadi jalan terapi efisien bagi kanker (Cao, Li, Hou, Yang, Fu, \& Zhao 2019). (+)/- Borneol juga dapat digunakan untuk terapi baru menangani gangguan ketakutan dan kecemasan (Cao et al., 2017), cedera iskemia otak (Dong et al., 2018), cedera otak akibat sepsis (Wang et al., 2019), stroke (Hu et al., 2019) serta terapi sakit kronis (Jiang et al., 2015). Peng (2017) juga melakukan penelitian mengenai borneol yang dikombinasikan dengan Asiaticoside, sehingga borneol diketahui memudahkan distribusi efek antidepresan pada otak, bahkan borneol disinyalir memiliki efek antidiabetes (Madhuri \& Ramachandra, 2017). Liu, Zhao, Guo, Liu, dan Liu, (2017) juga melakukan uji coba efek borneol terhadap mikroba patogen Candida albicans yang menyebabkan penyakit genital pada wanita, hasilnya diketahui bahwa kombinasi penggunaan borneol, berberine serta baicalein secara in vitro dan in vivo dapat menghambat Candica albicans lebih baik dibanding tanpa kombinasi dengan borneol. Borneol juga dikenal sebagai adjuvant efektif yang dapat meningkatkan pengiriman obat ke syaraf otak (Zhang et al., 2017), bahan penyusun parfum dan antiseptik (Gusmailina, 2015), meningkatkan penyerapan bioaktif dalam tubuh atau disebut penghantar obat (Liang et al., 2020), sehingga banyaknya manfaat borneol dalam bidang kesehatan menjadikan senyawa ini sebagai novel agent yang mampu memperbaiki taraf kesehatan manusia. Dari uraian tersebut, maka borneol sangat menjanjikan untuk dikembangkan karena merupakan produk turunan terpentin yang harganya paling tinggi dengan banyak manfaat.

Sintesis borneol dapat digunakan dengan beberapa cara, diantaranya ekstraksi atau isolasi batang getah pinus, namun cara ini pada umumnya 
hanya menghasilkan borneol yang terbatas dengan kemurnian yang kecil. Kebutuhan borneol di sektor industri sangat tinggi, sehingga hal ini mendorong produksi borneol dilakukan secara sintesis. Dari sini, perlu dikembangkan cara lain untuk dilakukan, yakni melalui reaksi esterifikasi $\alpha$-pinena menggunakan senyawa asam menjadi bornyl ester dan saponifikasi dengan senyawa basa menjadi borneol. Beberapa penelitian sebelumnya melaporkan sintesis borneol efektif dilakukan melalui mekanisme reaksi esterifikasi-saponifikasi $\alpha$-pinena menggunakan $\mathrm{CH}_{3} \mathrm{COOH}, \mathrm{H}_{2} \mathrm{SO}_{4}$, maupun $\mathrm{HCl}$. Reaksi esterifikasi $\alpha$-pinena menggunakan $\mathrm{HCl}$ disinyalir mampu memberikan konversi yang tinggi dengan produk utama berupa bornyl chloride dan isomer $\alpha$-pinena lain (Diana \& Budiman, 2018). Selanjutnya senyawa antara tersebut direaksikan menggunakan basa kuat seperti $\mathrm{NaOH}$ dan $\mathrm{KOH}$ agar menghasilkan produk borneol (Jin et al., 2011). Namun, hasil sintesis dari proses ini belum menunjukkan hasil yang optimal.

Pemanfaatan Hasil Hutan Bukan Kayu (HHBK) saat ini sedang dioptimalkan karena selain dapat mengisi kebutuhan masyarakat juga dapat meningkatkan nilai tambah produk HHBK tersebut (Daryono, 2015). Berdasarkan hal tersebut di atas (umumnya pemanfaatan dalam bentuk terpentin dan gondorukem), diversifikasi pemanfaatan terpentin di Indonesia belum cukup banyak, sehingga perlu dilakukan upaya pemanfaatannya menjadi berbagai produk terutama borneol dari turunan minyak terpentin yaitu $\alpha$-pinena. Oleh karena itu, tujuan dari penelitian ini adalah untuk menganalisis karakteristik borneol yang dihasilkan dari sintesis $\alpha$-pinena dengan menggunakan basa $\mathrm{NaOH}$ dan $\mathrm{KOH}$.

\section{BAHAN DAN METODE}

\section{A. Lokasi Penelitian}

Kegiatan sintesis dan pengujian borneol dilakukan di Laboratorium Pengolahan Hasil Hutan Bukan Kayu, Pusat Litbang Hasil Hutan Bogor, dan Pusat Laboratorium Forensik Polri Jakarta. Terpentin diperoleh dari pabrik getah pinus milik Perum Perhutani dari Sumedang, Jawa Barat, Pekalongan, Jawa Tengah dan Trenggalek, Jawa Timur.

\section{B. Bahan dan Alat}

Bahan kimia yang digunakan yaitu $\mathrm{HCl}$, aseton, etanol, metanol, kloroform, dietileter, $\mathrm{KOH}$ dan $\mathrm{NaOH}$. Alat yang digunakan adalah soxhlet, rotary vacuum evaporator, erlenmeyer, gelas kimia, destilasi kaca, gelas ukur, buret, kompor gas, spatula, ekstraktor, magnetic stirrer, kertas penyaring, timbangan, termometer, stopwatch, dan GCMS.

\section{Prosedur Kerja}

Bahan baku $\alpha$-pinena yang digunakan didapat dari hasil destilasi terpentin dari tiga lokasi. Hasil destilasi tersebut dilakukan pada suhu $162^{\circ} \mathrm{C}$ dan $167^{\circ} \mathrm{C}$ dengan kemurnian produk $\alpha$-pinena sekitar $85 \%$. Dalam proses sintesis digunakan asam kuat $\mathrm{HCl}(1 \%$ $\mathrm{b} / \mathrm{v})$ dan dua jenis basa kuat yaitu $\mathrm{NaOH}(1 \% \mathrm{~b} / \mathrm{v})$ dan $\mathrm{KOH}(1 \% \mathrm{~b} / \mathrm{v})$, sehingga didapat 12 sampel produk sintesis. Langkah awal yaitu $\alpha$-pinena ditambahkan dengan $\mathrm{HCl}$ menjadi bornyl cloride sebagai produk antara, kemudian, senyawa tersebut direaksikan masing-masing dengan basa kuat $\mathrm{NaOH}$ dan $\mathrm{KOH}$, sehingga diharapkan menjadi senyawa borneol (Besari Sulistyowati, \& Ishak, 1982).

Hasil borneol sintesis dikarakterisasi dengan FTIR (Fourier Transform Infrared Spectroscopy), Gas Chromatography-Mass Spectrometry (GCMS) dan Nuclear Magnetic Resonance (NMR) untuk mengetahui kemiripan senyawa dengan borneol hasil sintesis serta dibandingkan dengan spektra standar komponen senyawa dari SDBS (spectral database for organic compounds). Spektrum FTIR merupakan hasil pengukuran menggunakan spektrofotometer FTIR Tensor 37 (Bruker Optics GmbH, Karlsruhe, Jerman) di Laboratorium Pusat Studi Biofarmaka, IPB University, sedangkan NMR yang digunakan adalah spektrometer NMR (JNM-ECZ500R, 500 Mhz Super Conductive Magnets). Analisis data dilakukan secara deskriptif yaitu dengan membandingkan kadar borneol yang dihasilkan pada jenis basa dan asal terpentin.

\section{HASIL DAN PEMBAHASAN}

\section{A. Analisa FTIR Sintesis Borneol dari Senyawa $\alpha$-Pinena}

Hasil FTIR (spektroskopi inframerah) menunjukkan keberadaan gugus fungsional suatu senyawa tertentu. Setiap tipe ikatan (C-H, C-O, O-H, $\mathrm{C}-\mathrm{C}$, dan $\mathrm{C}=\mathrm{C}$ ) memiliki radiasi inframerah pada panjang gelombang karakteristik yang berlainan dan mengalami osilasi tertentu (Fessenden \& Fessenden, 1986). Senyawa $\alpha$-pinena ketika bereaksi dalam suasana asam akan membentuk senyawa turunan dan membentuk senyawa alkohol seperti $\alpha$-terpineol dan borneol (Amilia, Siadi, \& Latifah, 2015). Berikut struktur kimia dari $\alpha$-pinena, kamfer dan borneol (Gambar 1).

Pada penelitian ini, $\alpha$-pinena direaksikan dengan senyawa asam $(\mathrm{HCl})$ melalui reaksi esterifikasi, sehingga menghasilkan senyawa utama berupa bornyl chloride, mekanisme reaksi yang terjadi seperti ditunjukkan pada Gambar 2. Adapun mekanisme pembentukan senyawa kamfer dari $\alpha$-pinena melalui 


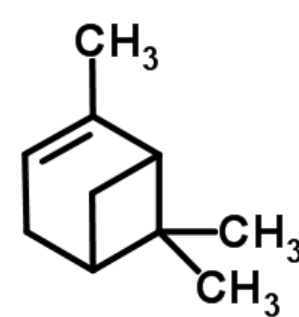

(a)

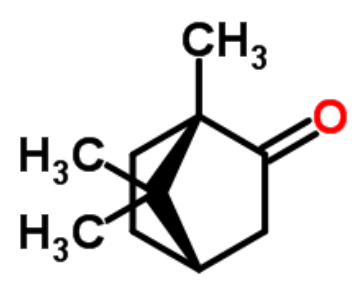

b)

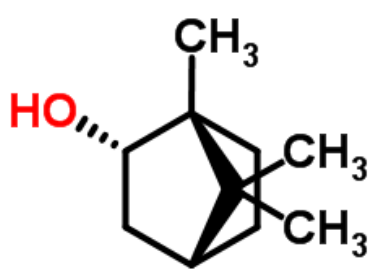

(c)

Gambar 1. Struktur kimia $\alpha$-pinena (a), kamfer (b) dan borneol (c)

Figure. 1. Chemical structure of a $\alpha$ pinena (a), camphor (b) dan borneol (c)

Sumber (Sources): National Institute of Advanced Industrial Science and Technology (AIST), Japan

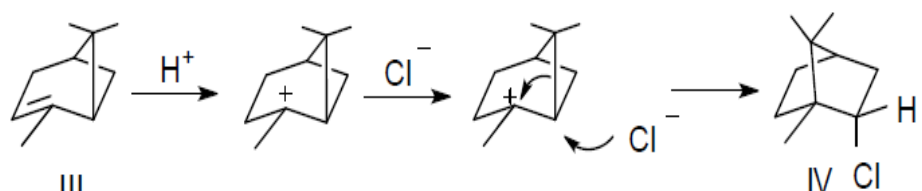

Gambar 2. Penambahan $\mathrm{HCl}$ pada $\alpha$-pinena

Figure 2. $\mathrm{HCl}$ addition to $\alpha$-pinena

Sumber (Sources): Ponomarev dan Mettee (2016)

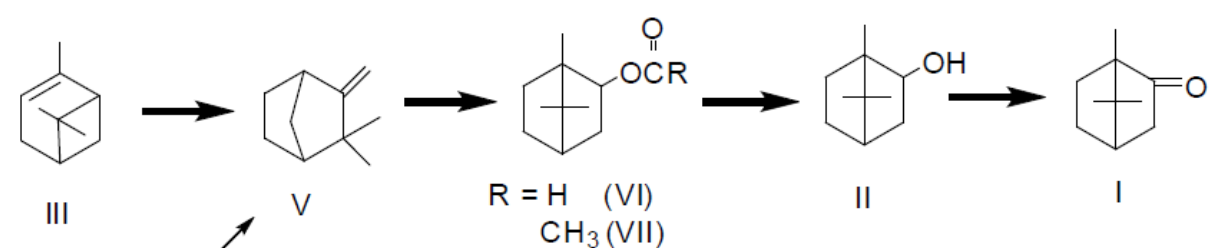<smiles>ClC1CC2CCC1(I)C2(Cl)I</smiles>

IV

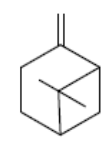

VIII

Gambar 3. Sintesis kamfer dari $\alpha$-pinena

Figure 3. Camphor synthesis from $\alpha$-pinena

Sumber: Ponomarev dan Mettee (2016)

mekanisme langsung melalui bornyl chloride maupun isomerisasi ditunjukkan pada Gambar 3.

Dari mekanisme tersebut, dapat dipahami bahwa kemungkinan pada penelitian ini juga masih didapatkan senyawa kamfer atau bornyl chloride yang masih tersisa dan belum bereaksi dengan basa, sehingga borneol yang didapat dari hasil sintesis berpeluang besar tercampur dengan senyawa lain. Senyawa kamfer ternyata juga merupakan senyawa monoterpen bisiklik yang dapat digunakan untuk pengharum, obat, serta makanan (Chandra \& Murthy, 2018). Selain dengan mekanisme reaksi tersebut, pembentukan senyawa kamfer juga dapat terjadi selama proses penyimpanan borneol jika dalam kondisi tidak stabil (Ren et al., 2019).

Di bawah ini merupakan gambar analisa FTIR standar dari $\alpha$-pinena, kamfer dan borneol (Gambar 4.) Terlihat perbedaan bentuk puncak maupun posisi absorbsi ikatan pada gelombang pada ketiga senyawa tersebut. Ada beberapa puncak yang penting untuk dilihat pada hasil analisis (standar FTIR di dapat dari data spektra untuk senyawa organik (SDBS).

Pada $\alpha$-pinena dan kamfer, gugus $\mathrm{OH}$ tidak muncul pada gelombang 3300-3600 $\mathrm{cm}^{-1}$ (Gambar 4a da 4b) sedangkan pada borneol vibrasi ulur 

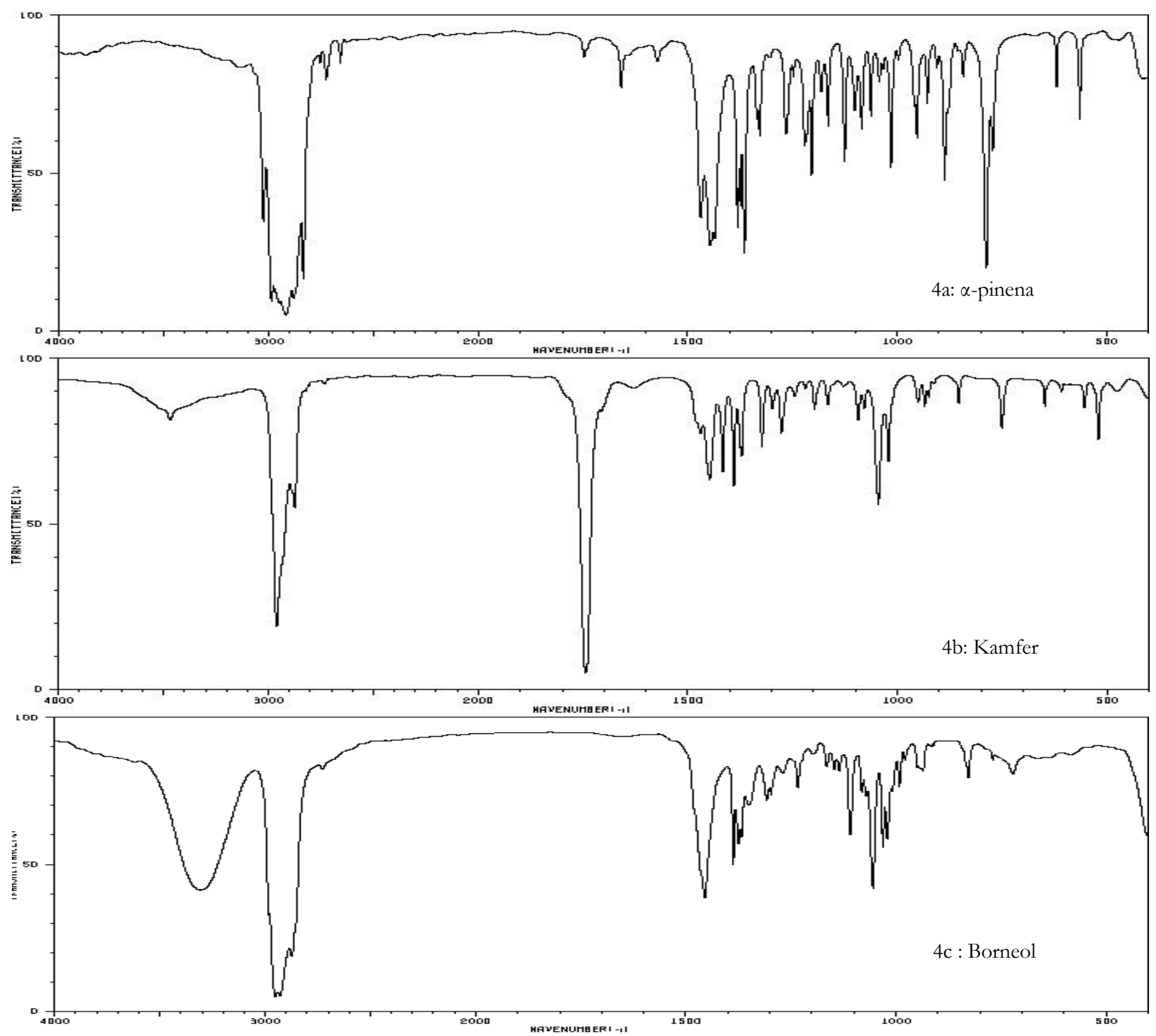

Gambar 4. Serapan FTIR standar $\alpha$-pinena (4a), kamfer (4b) dan borneol (4c)

Figure 4. FTIR spectroscopy of $\alpha$-pinene (4a), camphor (4b) and borneol standard (4c)

Sumber (Sources): National Institute of Advanced Industrial Science and Technology (AIST), Japan

gugus $\mathrm{OH}$ muncul pada bilangan gelombang sekitar 3300-3600 $\mathrm{cm}^{-1}$ dengan bentuk puncak yang cukup melebar (Gambar 4c). Kemudian ikatan C-H muncul pada bilangan gelombang sekitar $2900 \mathrm{~cm}^{-1}$, ini terlihat di hasil analisis ketiga senyawa tersebut namun pada borneol ikatan $\mathrm{C}-\mathrm{H}$ ini lebih lemah ditandai dengan puncak yang tidak terlalu tajam dibanding $\alpha$-pinena maupun kamfer, dan ikatan karbonil $\mathrm{C}=\mathrm{O}$ muncul dengan intensitas kuat yang ditandai dengan puncak yang tajam pada analisis senyawa kamfer sedangkan untuk $\alpha$-pinena dan borneol tidak dijumpai ikatan karbonil tersebut. Serapan pada gelombang
$1400 \mathrm{~cm}^{-1}$ dengan intensitas medium juga dapat dilihat pada analisa standar borneol yang menunjukkan adanya ikatan C-C yang lebih kuat dibanding pada $\alpha$-pinena maupun kamfer. Beberapa tipe ikatan ini menjadi standar acuan serapan pada senyawa borneol. Contoh salah satu pola spektra hasil analisis FTIR dari produk borneol sintesis hasil reaksi $\alpha$-pinena asal Jawa Barat menggunakan $\mathrm{NaOH}$ disajikan pada Gambar 5.

Analisis FTIR sampel hasil sintesis borneol menunjukkan puncak-puncak absorpsi yang cukup serupa dengan puncak yang muncul pada FTIR 


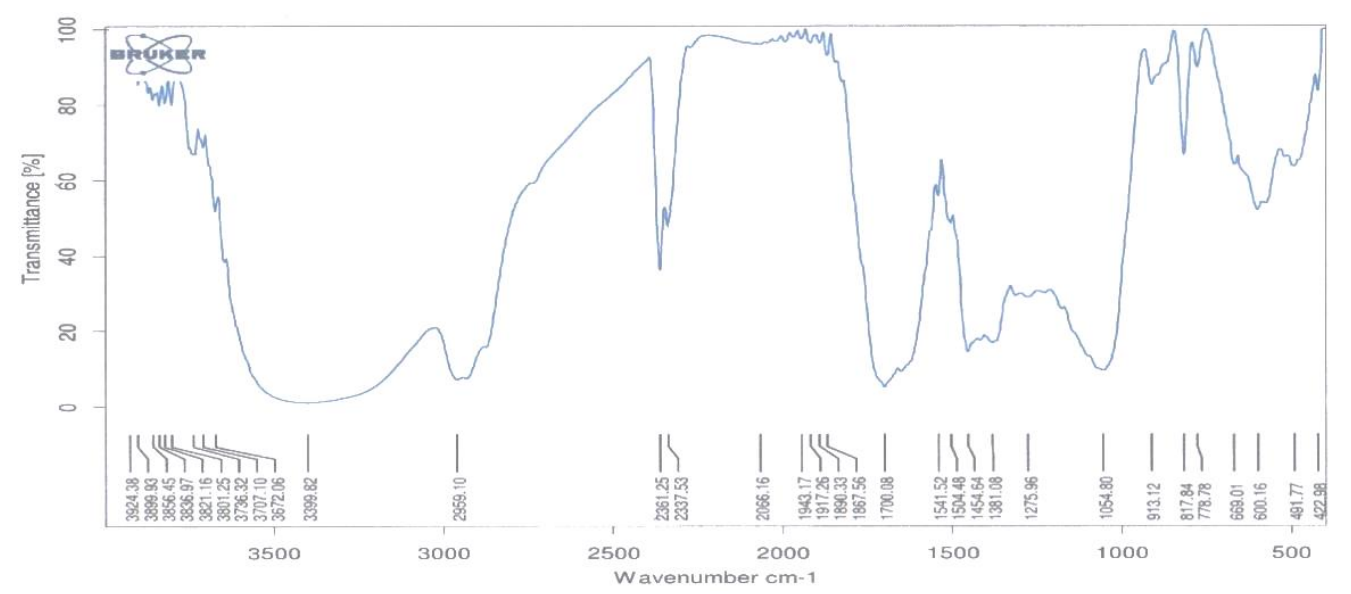

\section{Gambar 5. Serapan FTIR borneol sintesis asal Jawa Barat Figure 5. FTIR spectroscopy of syntesized borneol from West Java}

standar borneol. Hal ini ditandai dengan munculnya beberapa puncak absorbsi yang memiliki gelombang serapan yang hampir sama bila dibandingkan dengan serapan pada borneol. Puncak-puncak tersebut muncul dengan intensitas lemah hingga sedang dengan pelebaran sedikit pada bentuk puncak. Beberapa puncak yang penting pada borneol diantaranya pada serapan $3.300 \mathrm{~cm}^{-1}, 2.950 \mathrm{~cm}^{-1}$, $1.454 \mathrm{~cm}^{-1}$, dan $1.055 \mathrm{~cm}^{-1}$ (Gambar 4c). Penelitian Li et al. (2017) juga mengemukakan bahwa puncak serapan keberhasilan grafting borneol pada graphene ditandai dengan peningkatan serapan pada bilangan gelombang terutama pada $1.175 \mathrm{~cm}^{-1}$. Serapan pada bilangan gelombang 1.100 -an $\mathrm{cm}^{-1}$ dan 1.700 -an $\mathrm{cm}^{-1}$ diketahui menjadi penanda struktur borneol pada penelitian Hong et al. (2019).

Data spektra FTIR ke-12 sampel produk borneol sintesis pada penelitian ini disajikan pada Tabel 1 . Dari tabel tersebut, dapat kita lihat bahwa pada borneol, terdapat ikatan O-H pada bilangan gelombang 3.300-3.600 $\mathrm{cm}^{-1}$ dan pada kedua belas sampel ikatan O-H ini terlihat keberadaannya dengan puncak serapan bervariatif antar sampel berkisar 3.389,83-3.429,5 cm. Semua sampel borneol sintesis juga menghasilkan spektra ikatan pada bilangan gelombang $1.075-1.180 \mathrm{~cm}^{-1}$ serta bilangan gelombang 1.699-1.706 $\mathrm{cm}^{-1}$, sehingga seluruh sampel produk hasil reaksi bahan baku 3 wilayah (Jabar, Jateng dan Jatim) dengan basa $\mathrm{KOH}$ dan $\mathrm{NaOH}$ tidak terlalu memiliki pola ikatan yang berbeda.

Ikatan O-H ini merupakan ikatan lemah vibrasi ulur yang diindikasikan terikat dengan ikatan hidrogen atau sampel yang diuji masih mengandung air karena bentuk puncak serapan melebar, tidak tajam dan bergeser ke arah bilangan gelombang yang lebih pendek. Kemudian ikatan C-H alifatik terdapat pada semua sampel yang ditunjukkan oleh serapan dengan variasi absropsi pada panjang gelombang 2.957$2.969,08 \mathrm{~cm}^{-1}$ yang diakibatkan oleh vibrasi ulur dari cincin aromatik. Selanjutnya untuk ikatan C-O terlihat pada variasi bilangan gelombang $1.050-1100 \mathrm{~cm}^{-1} \mathrm{dan}$ ikatan C-C aromatik pada bilangan gelombang 1.454$1.456 \mathrm{~cm}^{-1}$ dengan derajat subtitusi yang rendah.

Dari hasil spektra IR juga terlihat beberapa puncak di luar penyusun borneol, yaitu ikatan $\mathrm{C}=\mathrm{O}$ pada bilangan gelombang $1.699-1.706 \mathrm{~cm}^{-1}$ yang khas dan dihasilkan oleh vibrasi ikatan rangkap. Kemudian juga ditemukan vibrasi ulur dari ikatan $-C$ rangkap 3 pada bilangan gelombang $2.250-2.300 \mathrm{~cm}^{-1}$ serta serapan pada bilangan gelombang $1.370 \mathrm{~cm}^{-1}$ kemungkinan ikatan nitro aromatik dan $817 \mathrm{~cm}^{-1}$ untuk ikatan C-C dari alkane. Daerah sidik jari (finger print) berada pada $500-1.400 \mathrm{~cm}^{-1}$ dimana sedikit saja perbedaan dalam struktur dan susunan molekul maka akan menyebabkan distribusi puncak absorpsi berubah, sehingga dari penjelasan tersebut disinyalir bahwa hasil sintesis borneol dari $\alpha$-pinena masih belum seluruhnya murni karena kemungkinan masih berisi senyawa kamfer dan produk samping lainnya.

\section{B. Analisa NMR Sintesis Borneol dari $\alpha$-pinena}

Pada akhir sintesis juga dilakukan uji NMR untuk mengetahui struktur komponen suatu senyawa kimia dan kemurnian komponennya (Gambar 6 \& 7). Dari hasil analisis NMR baik itu HNMR dan CNMR jika dibandingkan dengan standar NMR senyawa $\alpha$ pinena, kamfer dan borneol, maka dapat dilihat bahwa puncak-puncak serapan menunjukkan perbedaan yang cukup jauh dengan ketiga senyawa tersebut. Hal ini diduga karena hasil sintesis masih berupa crude atau campuran komponen dan belum murni borneol, sehingga perhitungan komponen 
Tabel 1. Data serapan FTIR 12 borneol sintesis

Table 1. FTIR spectroscopy data of 12 synthesized borneol

\begin{tabular}{|c|c|c|c|c|c|c|c|c|c|c|c|c|c|}
\hline No. & $\begin{array}{l}\text { Ikatan } \\
\text { (Bond) }\end{array}$ & & & & & & & $\begin{array}{l}\text { e Sampel } \\
\text { mple code) }\end{array}$ & & & & & \\
\hline & & I.12 & I.17 & I.22 & I. 27 & II.I2 & II.17 & II.22 & II.27 & III.12 & III.17 & III.22 & III.27 \\
\hline 1. & $\mathrm{O}-\mathrm{H}$ & 3418,82 & 3394,95 & 3422,90 & 3416,05 & 3416,26 & 3424,69 & 3425,29 & 3400,55 & 3429,50 & 3399,12 & 3399,82 & 3389,83 \\
\hline 2. & $\mathrm{C}-\mathrm{H}$ & 2969,08 & 2958,06 & 2958,17 & 2958,02 & 2968,09 & 2961,73 & 2961,79 & 2958 & 2958,33 & 2957,97 & 2959,10 & 2957 \\
\hline 3. & $-C=C$ & 2361,32 & 2362,10 & 2360,74 & 2361,25 & 2361,26 & 2361,47 & 2361,33 & 2361,34 & 2361,58 & 2361,43 & 2361,25 & 2361,35 \\
\hline 4. & $\mathrm{C}=\mathrm{O}$ & 1704,23 & 1702,97 & 1703,26 & 1703,21 & 1701,69 & 1706,68 & 1706,30 & 1703,63 & 1705,46 & 1703,43 & 1700,08 & 1699,54 \\
\hline 5. & $\mathrm{C}-\mathrm{C}$ & 1456,93 & 1455,86 & 1456,54 & 1456,99 & 1456,19 & 1456,08 & 1456,14 & 1456,86 & 1456,75 & 1456,86 & 1454,64 & 1454,40 \\
\hline 6. & $\mathrm{C}-\mathrm{O}$ & 1114,35 & 1075,60 & 1114,57 & 1147,21 & 1076,85 & 1121,67 & 1121,79 & 1075,56 & 1181,30 & 1075,01 & 1054,8 & 1057,33 \\
\hline 7. & & 1370,24 & 1370,81 & 1370,01 & 1369,99 & 1370,26 & 1371,32 & 1371,21 & 1369,94 & 1371,55 & 1369,85 & 1381,08 & - \\
\hline
\end{tabular}

Keterangan (Remarks): Jateng (Central Java), Jabar (West Java), Jatim (East Java);

$\mathrm{I} .12=$ Jateng, $\mathrm{KOH}, 162^{\circ} \mathrm{C}$; I17 = Jateng, $\mathrm{KOH}, 167^{\circ} \mathrm{C}$; I.22 = Jateng, $\mathrm{NaOH}, 162^{\circ} \mathrm{C} ; \mathrm{I} .27=$ Jateng, $\mathrm{NaOH}, 167^{\circ} \mathrm{C}$;

II.12 = Jabar, $\mathrm{KOH}, 162^{\circ} \mathrm{C}$; II.17 = Jabar, $\mathrm{KOH}, 167^{\circ} \mathrm{C}$; II.22 = Jabar, NaOH, $162^{\circ} \mathrm{C}$; II. $27=\mathrm{Jabar}, \mathrm{NaOH}, 167^{\circ} \mathrm{C}$;

III.12 = Jatim, $\mathrm{KOH}, 162^{\circ} \mathrm{C}$; III.17 = Jatim, $\mathrm{KOH}, 167^{\circ} \mathrm{C}$; III.22 = Jatim, NaOH, $162^{\circ} \mathrm{C}$; III. 27 = Jatim, NaOH, $167^{\circ} \mathrm{C}$ 


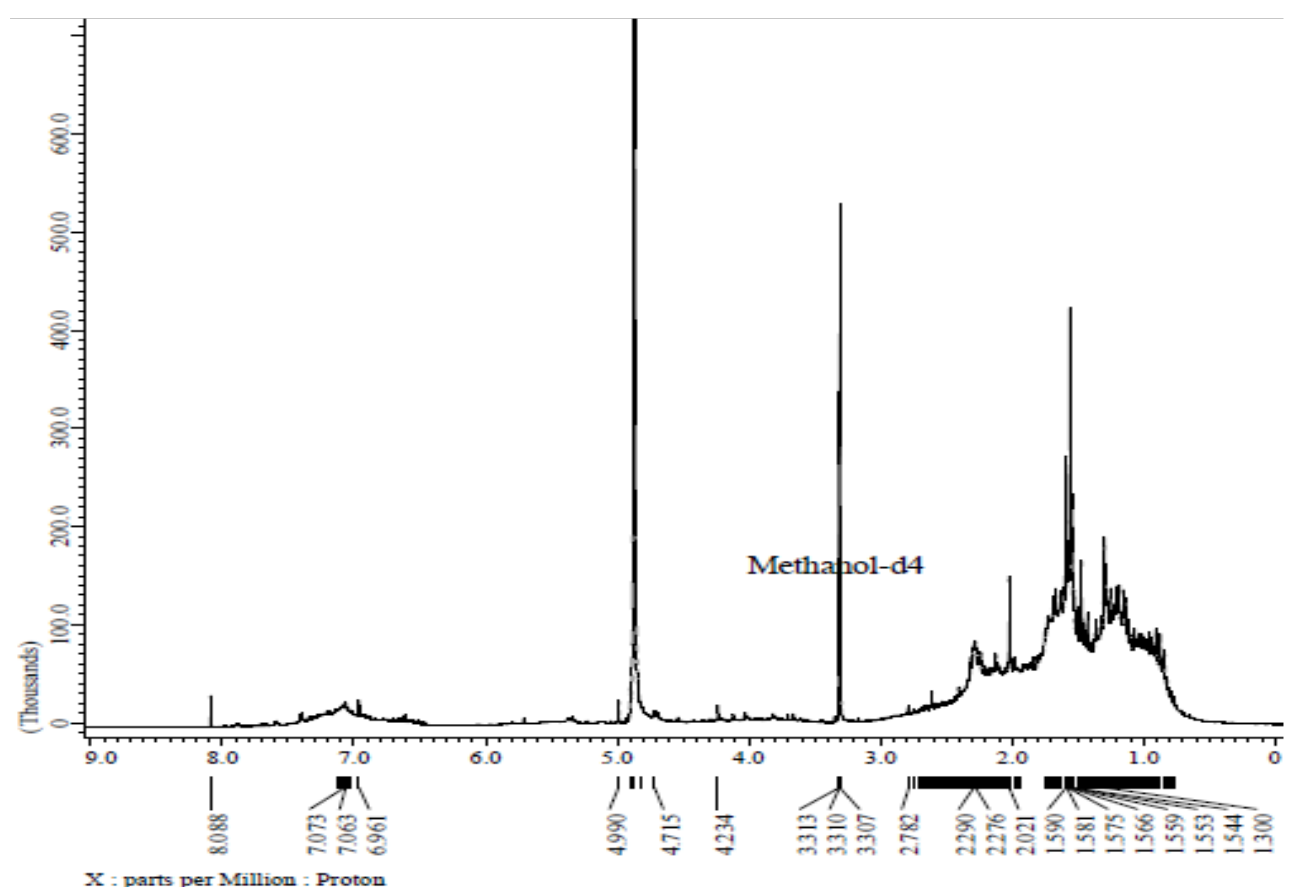

Gambar 6. HNMR borneol sintesis

Figure 6. HNMR syinthesized borneol

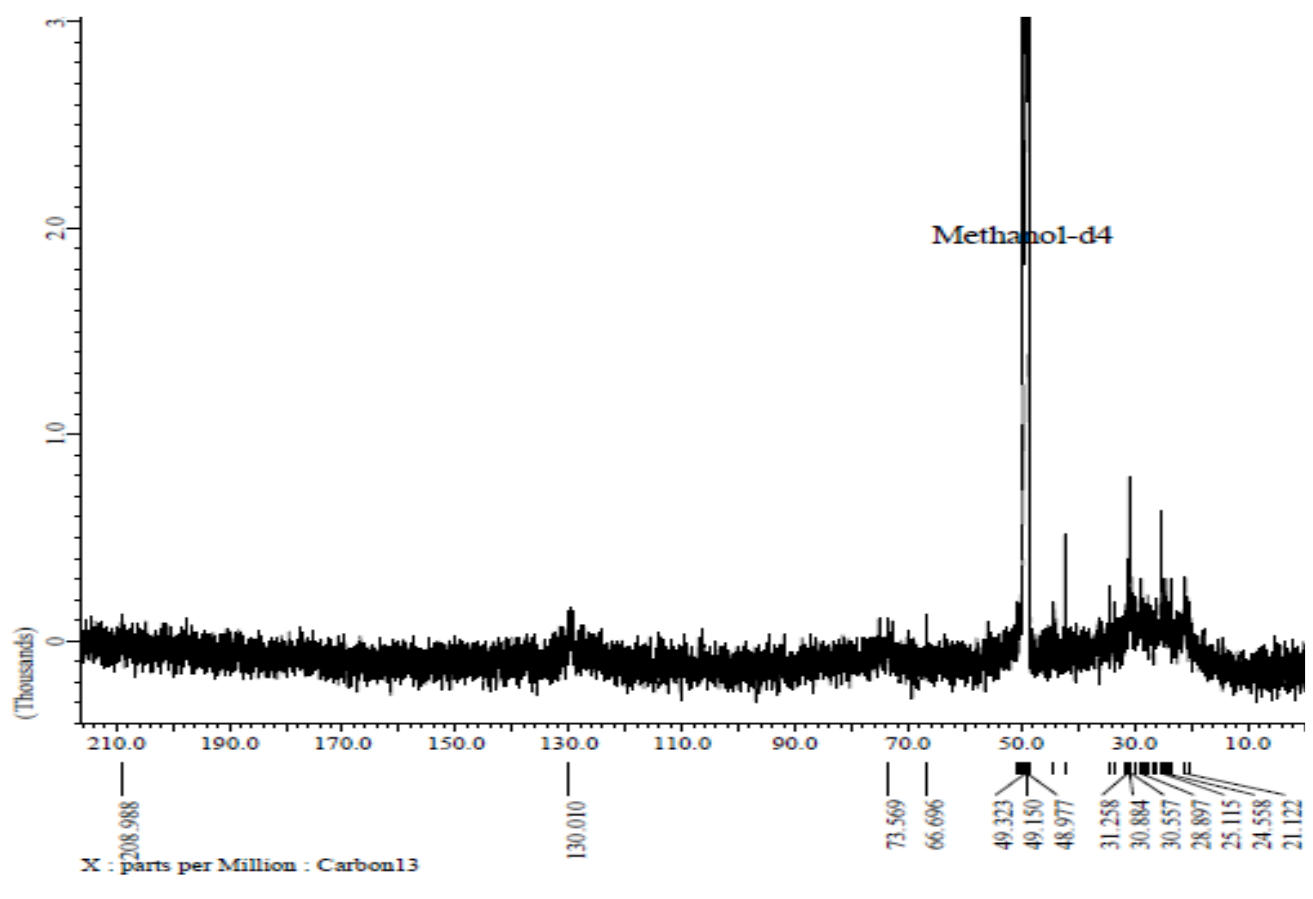

Gambar 7. CNMR borneol sintesis

Figure 7. CNMR syinthesized borneol

maupun struktur komponen sulit diketahui melalui NMR karena puncak serapan tidak terlihat jelas bentuk pergeseran kimianya.

Menurut Pavia, Kriz, dan Gary (2005), pergeseran kimia penciri borneol yaitu gugus hidroksi yang terikat pada C-H muncul pada 4 ppm dan 3,6 ppm untuk isoborneol, dari hasil analisa NMR borneol sintesis ditemukan pergeseran kimia di daerah tersebut yaitu di 4,234 ppm namun dengan sinyal lemah, diduga karena hasil sintesis masih belum 
murni dan mengandung produk samping lain yang lebih banyak karena pergeseran kimia yang banyak terlihat justru di angka 0,8-2,4 ppm. Pada Tabel 2 dan 3 dijelaskan beberapa pergeseran kimia untuk senyawa borneol berdasarkan data standar SDBS dan NOP.

Pada hasil analisis NMR diketahui terdapat senyawa borneol serta isoborneol yang terbentuk, hal ini diduga terjadi karena senyawa kamfer yang terbentuk mengalami reaksi reduksi. Isoborneol merupakan salah satu bentuk stereoisomer dari borneol, dan melalui metode reaksi reduksi pada kamfer, maka produk yang terbentuk pada umumnya tidak murni dan mengandung empat stereoisomer dari borneol yaitu ( (+) -isoborneol, (-)-isoborneol, (+)-borneol dan (-)- borneol (Ho, Hung, \& Shih, 2018). Armaka, Papanikolaou, Sivropoulou, dan Arsenakis (1999) melaporkan hasil penelitiannya, bahwa senyawa isoborneol juga banyak memiliki manfaat diantaranya sifat antivirus atau efek inhibitor terhadap virus herpes simpleks tipe 1 pada konsentrasi penggunaan 0,06\%. Hu et al., (2019) melaporkan bahwa borneol juga dapat dimanfaatkan sebagai kombinasi yang memberikan pengaruh luar biasa pada penggunaan tetrametilpirazin, sehingga memberi efek terapetik yang baik pada penyakit struk. (+)-Borneol umumnya diperoleh dari tanaman alam dengan pertumbuhan yang lambat seperti Dipterocarpus turbinatus, sehingga borneol dengan isomer ini memiliki harga yang lebih tinggi ( \pm US\$ 118 per gram) dibanding (-)- borneol (US\$ 122 per gram) dari B. balsamifera apalagi jika dibandingkan dengan harga borneol hasil sintesis kimia hanya bernilai US $\$ 30$ per $k g$ (Ho, Hung, \& Shih, 2016).

\section{Kandungan Senyawa Kimia Hasil Sintesis}

Analisis spektroskopi massa kromatografi gas (GCMS) pada semua sampel yang diuji menunjukkan terbentuknya senyawa borneol dalam jumlah persen relatif yang berbeda-beda. Pada Tabel 4 di bawah ini disajikan persentase relatif kandungan senyawa borneol sintesis dari 12 (dua belas) perlakuan yang dilakukan. Kandungan persen relatif borneol diperoleh pada waktu retensi sekitar 4 menit (Gambar 8).

Dari Tabel 4, dapat dilihat bahwa persentase hasil sintesis borneol asal 3 wilayah menghasilkan persen relatif produk yang berbeda dengan produk tertinggi dihasilkan oleh reaksi $\alpha$-pinena asal jawa Barat menggunakan basa $\mathrm{NaOH}$. Hasil penelitian ini menunjukkan, bahwa sintesis borneol dengan metode reaksi yang digunakan pada penelitian ini dapat menghasilkan borneol dengan kisaran $0,12-2,03 \%$.

Secara umum, persentase borneol yang dihasilkan masih sangat kecil, kemungkinan dikarenakan beberapa hal, diantaranya proses reaksi dengan $\mathrm{HCl}$ yang tidak optimal, perlunya penambahan katalis pada mekanisme reaksi awal sehingga selektivitas terhadap produk antara cukup baik, terbentuknya produk samping yang tinggi serta pemisahan produk yang sulit karena memiliki fasa yang sama. Demikian juga dengan penggunaan senyawa $\mathrm{KOH}$ maupun $\mathrm{NaOH}$ merupakan senyawa bersifat basa kuat, yang umum digunakan dalam proses sintesis borneol, namun ukuran molekul kalium lebih besar daripada natrium, sehingga reaksi berjalan lambat dan kemungkinan membentuk produk samping yang lebih banyak.

Tabel 2. Perkiraan pergeseran kimia HNMR borneol dan isoborneol standar dengan borneol sintesis Table 2. Chemical shift predicted of borneol HNMR and isoborneol standard with borneol synthesized

\begin{tabular}{|c|c|c|c|c|c|}
\hline $\begin{array}{c}\text { Pergeseran kimia } \\
\text { (Chemical shift, ppm) } \\
\text { bornoel + isoborneol }\end{array}$ & $\begin{array}{l}\text { Ikatan } \\
\text { (Bond) }\end{array}$ & $\begin{array}{r}\text { Per } \\
\text { born } \\
(C \\
\text { synthes. }\end{array}$ & $\begin{array}{l}\text { eseran } 1 \\
\text { l hasil } \\
\text { mical sh } \\
\text { ed borne }\end{array}$ & $\begin{array}{l}\text { nia } \\
\text { tesis } \\
\text { of } \\
\text { ppm) }\end{array}$ & $\begin{array}{l}\text { Ikatan } \\
\text { (Bond) }\end{array}$ \\
\hline 0,82 & $\mathrm{CH}_{3}$ isoborneol & 0,872 & & & $\mathrm{CH}_{3}$ isoborneol \\
\hline 0,91 & $\mathrm{CH}_{3}$ isoborneol & 0,906 & & & $\mathrm{CH}_{3}$ isoborneol \\
\hline 1,02 & $\mathrm{CH}_{3}$ isoborneol & 1,028 & & & $\mathrm{CH}_{3}$ isoborneol \\
\hline $3,58-3,65$ & $\mathrm{CH}-\mathrm{OH}$ isoborneol & - & & & - \\
\hline $3,96-4,40$ & $\mathrm{CH}-\mathrm{OH}$ borneol & 4,234 & & & $\mathrm{CH}-\mathrm{OH}$ borneol \\
\hline $0,8-2,4$ & $\mathrm{H}$ (produk lain) & $\begin{array}{l}0,715 \\
1,862 \\
2,276\end{array}$ & $\begin{array}{r}0,718 ; \\
1,984 ; \\
2,4\end{array}$ & $\begin{array}{l}\text { 1,474; } \\
2,021 ;\end{array}$ & H (produk lain) \\
\hline
\end{tabular}


Tabel 3. Perkiraan pergeseran kimia CNMR borneol dan isoborneol standar dengan borneol sintesis Table 3. Chemical shift predicted of borneol CNMR and isoborneol standard with borneol synthesized

\begin{tabular}{|c|c|c|c|}
\hline $\begin{array}{l}\text { Pergeseran kimia } \\
\text { (Chemical shift, ppm ) } \\
\text { bornoel+isoborneol }\end{array}$ & $\begin{array}{l}\text { Ikatan } \\
\text { (Bond) }\end{array}$ & $\begin{array}{c}\text { Pergeseran kimia } \\
\text { borneol hasil sintesis } \\
\text { (Chemical shift of } \\
\text { synthesized borneol, ppm) }\end{array}$ & $\begin{array}{l}\text { Ikatan } \\
\text { (Bond) }\end{array}$ \\
\hline 11,33 & $\mathrm{CH}_{3}(1$ metil isoborneol $)$ & - & - \\
\hline 20,12 & $\mathrm{CH}_{3}$ (7 metil isoborneol) & 20,24 & $\mathrm{CH}_{3}$ (7 metil isoborneol) \\
\hline 20,49 & $\mathrm{CH}_{3}$ (7 metil isoborneol) & - & - \\
\hline 27,25 & $\mathrm{C} 5, \mathrm{CH}_{2}$ isoborneol & 27,70 & $\mathrm{C} 5, \mathrm{CH}_{2}$ isoborneol \\
\hline 33,92 & $\mathrm{C} 6, \mathrm{CH}_{2}$ isoborneol & 33,61 & $\mathrm{C} 6, \mathrm{CH}_{2}$ isoborneol \\
\hline 40,41 & $\mathrm{C} 3, \mathrm{CH}_{2}$ isoborneol & - & - \\
\hline 45,05 & $\mathrm{C} 4, \mathrm{CH}$ isoborneol & - & - \\
\hline 46,35 & $\mathrm{C} 7, \mathrm{C}$ quart isoborneol & - & - \\
\hline 48,97 & $\mathrm{C} 1, \mathrm{C}$ quart isoborneol & 48,97 & $\mathrm{C} 1, \mathrm{C}$ quart isoborneol \\
\hline 79,92 & $\mathrm{C} 2, \mathrm{CHOH}$ isoborneol & - & - \\
\hline 13,34 & $\mathrm{CH}_{3}$ (1 metilborneol) & - & - \\
\hline 18,69 & $\mathrm{CH}_{3}$ (7metilborneol) & - & - \\
\hline 20,20 & $\mathrm{CH}_{3}$ (7 metilborneol) & 20,248 & $\mathrm{CH}_{3}$ (7 metilborneol) \\
\hline 25,93 & $\mathrm{C} 6, \mathrm{CH}_{2}$ borneol & 25,11 & $\mathrm{C} 6, \mathrm{CH}_{2}$ borneol \\
\hline 28,29 & $\mathrm{C} 5, \mathrm{CH}_{2}$ borneol & 28,89 & $\mathrm{C} 5, \mathrm{CH}_{2}$ borneol \\
\hline 39,04 & $\mathrm{C} 3, \mathrm{CH}_{2}$ borneol & - & - \\
\hline 45,11 & $\mathrm{CH}, \mathrm{CH}$ borneol & - & - \\
\hline 48,03 & C7, C quart borneol & 48,64 & C7, C quart borneol \\
\hline 49,50 & C1, C quart borneol & 49,48 & C1, C quart borneol \\
\hline 77,21 & $\mathrm{C} 2, \mathrm{CHOH}$ borneol & - & - \\
\hline
\end{tabular}

Tabel 4. Persentase relatif kandungan senyawa borneol Table 4. Relative percentage of borneol compound

\begin{tabular}{|c|c|c|c|c|}
\hline No. & $\begin{array}{c}\text { Asal } \\
\text { (Originated) }\end{array}$ & $\begin{array}{c}\text { Jenis Basa } \\
\text { (Alkali) }\end{array}$ & $\begin{array}{l}\text { Suhu destilasi } \\
\text { (Distillation } \\
\text { temperature, }{ }^{\circ} \mathrm{C} \text { ) }\end{array}$ & $\%$ borneol \\
\hline 1. & Jawa Tengah & $\mathrm{KOH}$ & 162 & 0.39 \\
\hline 2. & (Central java) & & 167 & 1.36 \\
\hline 3. & & $\mathrm{NaOH}$ & 162 & 0.49 \\
\hline 4. & & & 167 & 0.13 \\
\hline 5. & Jawa Barat & $\mathrm{KOH}$ & 162 & 0.66 \\
\hline 6. & (West java) & & 167 & 0.77 \\
\hline 7. & & $\mathrm{NaOH}$ & 162 & 2.03 \\
\hline 8. & & & 167 & 0.24 \\
\hline 9. & Jawa Timur & $\mathrm{KOH}$ & 162 & 1.17 \\
\hline 10. & (East java) & & 167 & 0.52 \\
\hline 11. & & $\mathrm{NaOH}$ & 162 & 1.00 \\
\hline 12. & & & 167 & 0.12 \\
\hline
\end{tabular}




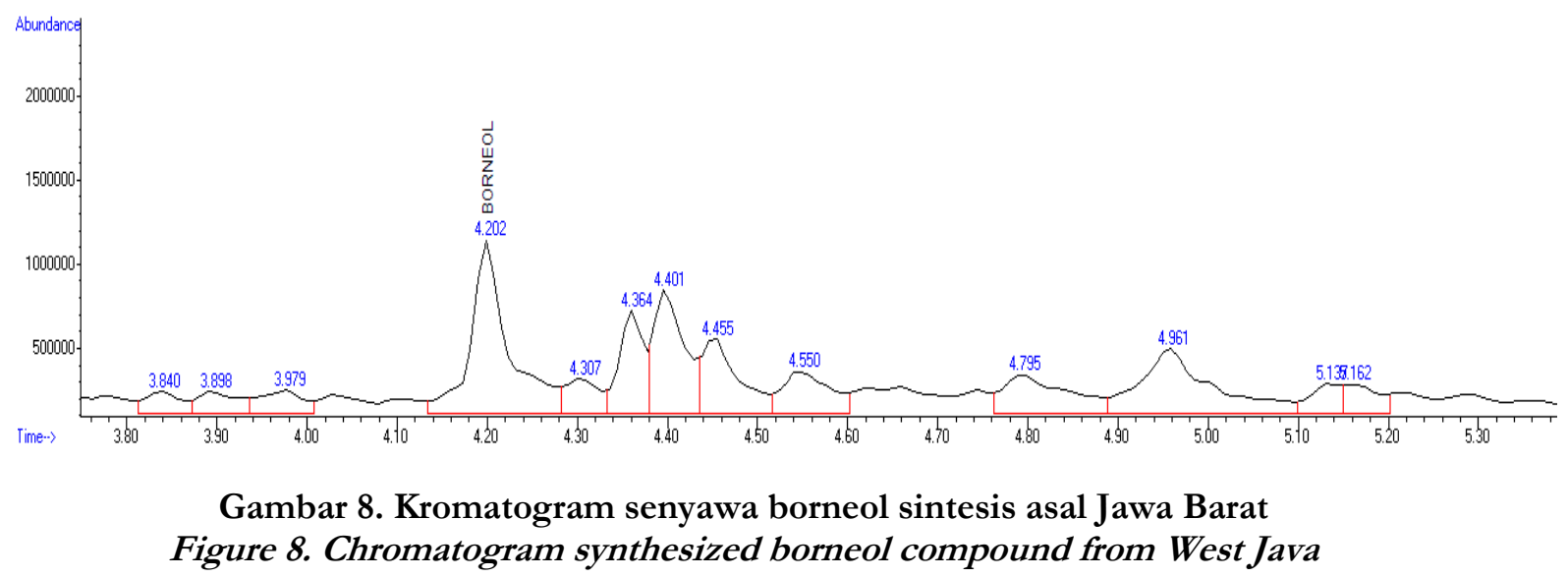

Produk antara yang didapat pada reaksi awal dengan $\mathrm{HCl}$ tentu saja akan mempengaruhi reaksi selanjutnya dengan basa, baik dengan $\mathrm{KOH}$ maupun $\mathrm{NaOH}$., sehingga produk akhir tidak murni dan masih mengandung isoborneol (sejalan dengan hasil analisis NMR). Hasil ini juga dinilai masih rendah apabila dibandingkan dengan penelitian Shanghe, Meyu, dan Xing (2010) yang mendapatkan borneol dari $\alpha$-pinena melalui reaksi esterifikasi menggunakan asam oksalat dan katalis $\mathrm{B} / \mathrm{Ti}$ dengan persentase rerata $64 \%$. Namun, pada penelitian Qi, Gao, Zhang, Wei, dan Bi (2013) diperoleh informasi bahwa penggunaan borneol hanya sebanyak $0,2 \%$ dapat meningkatkan permeasi transkornea dan bersifat tidak mengiritasi mata, sehingga borneol bisa dipertimbangkan menjadi penetrasi yang aman, efektif untuk membantu perawatan mata.

Berikut salah satu kromatogram GCMS produk sintesis borneol dari $\alpha$-pinena asal Jawa Barat yang dihasilkan melalui reaksi menggunakan $\mathrm{NaOH}$ (Gambar 8). Dari Gambar 8, dapat dilihat bahwa puncak kromatogram borneol terlihat muncul pada waktu retensi sekitar 4,2 menit dengan persentase produk sebesar $2,03 \%$, termasuk produk dengan hasil tertinggi pada penelitian ini.

Senyawa champene juga ditemukan pada proses sintesis $\alpha$-pinena ini. Senyawa ini merupakan senyawa prekursor untuk senyawa kamfer dan borneol. Senyawa ini juga dapat digunakan pada industri farmasi dan kosmetik, terbentuk dari 2 langkah reaksi yaitu pembentukan bornil klorida dari reaksi $\alpha$-pinena dengan $\mathrm{HCl}$ kemudian diubah menjadi champene dengan garam logam dari asam karboksilat (Roma'nAguirre, Gochi, Sanchez, Torre, \& AguilarElguezabal, 2008). Seperti diketahui bahwa isomerisasi $\alpha$-pinena melewati mekanisme reaksi tertentu sehingga menghasilkan 2 jenis produk turunan yaitu senyawa monosiklik seperi limonene, terpinen, dan ternolene serta senyawa polisiklik termasuk champene, pinena, dan tricyclene dan proses tersebut banyak menggunakan katalis seperti katalis mesopori sebagai bantuan untuk memaksimalkan konversi dan selektivitas produk (Frattini et al., 2017). Reduksi $\alpha$ pinena melalui reaksi hidrogenasi juga pernah dilaporkan Ndongou et al. (2018) menggunakan katalis heterogen sehingga membentuk senyawa cispinan yang lebih bernilai.

Salah satu bentuk sintesis $\alpha$-pinena yang pernah dilaporkan adalah sintesis $\alpha$-pinene menjadi $\alpha$ terpineol menggunakan $\mathrm{H}_{2} \mathrm{SO}_{4}$ dengan variasi suhu reaksi dan volume etanol. Penelitian ini menghasilkan konsentrasi $\alpha$-terpineol tertinggi sebesar $57,05 \%$ dengan yield $67,79 \%$ pada suhu $70^{\circ} \mathrm{C}$ dan volume etanol $135 \mathrm{~mL}$ (Daryono, 2015). Isomerisasi $\alpha$ dan $\beta$ pinena dilaporkan juga oleh (Sánchez-velandia, Gelves, Dorkis, Márquez, \& Villa, 2019) menggunakan katalis mikro dan mesopori MCM-41 dan SBA 15 yang diimpregnasi logam $\mathrm{Fe}$ dan $\mathrm{Cu}$, sehingga menghasilkan selektivitas katalis sebesar $59 \%$ terhadap senyawa campholenic aldebyde. Senyawa $\alpha$ pinena juga memiliki bentuk enantiomer yang dapat menentukan fungsi dan interaksinya, karena pada jumlah yang sama jika bentuk enantiomer berbeda maka interaksi dengan senyawa lain akan berbeda, sehingga memiliki sifat antimikroba yang juga berbeda, seperti enantiomer $\mathrm{S}<\mathrm{R} \alpha$-pinena asal Juniperus communis lebih kuat menghambat pertumbuhan bakteri dan Candida sedangkan $\mathrm{S}=\mathrm{R}$ lebih mampu menghambat Trichophyton dan Aspergillus (Lo, Jurgita, Pa, \& Raudonien, 2018). Lebih lanjut, proses perolehan $\alpha$-pinena dan senyawa turunannya seperti borneol perlu dikaji secara mendalam agar dapat menghasilkan rendemen dan selektivitas produk yang optimal, sehingga dapat dimanfaatkan secara luas untuk berbagai tujuan. 


\section{KESIMPULAN DAN SARAN}

\section{A. Kesimpulan}

Analisis FTIR dari 12 sampel hasil sintesis borneol menunjukkan puncak-puncak absorpsi yang cukup serupa dengan puncak yang muncul pada FTIR standar borneol. Hasil analisis NMR baik itu HNMR dan CNMR, jika dibandingkan dengan standar NMR senyawa $\alpha$-pinena, kamfer dan borneol, maka dapat dilihat bahwa puncak-puncak serapan masih menunjukkan adanya produk samping hasil reaksi. Hasil GCMS menunjukkan terbentuknya sintesis senyawa borneol dengan persentase relatif 0,12 $2,03 \%$. Sintesis menggunakan basa $\mathrm{KOH}$ dan $\mathrm{NaOH}$ tidak menunjukkan perbedaan dalam kadar borneol. Asal terpentin yang digunakan juga tidak menunjukkan adanya perbedaan kadar borneol. Secara keseluruhan, produk sintesis yang terbentuk masih mengandung senyawa-senyawa kimia lain sebagai hasil samping maupun prekursor yang belum terkonversi.

\section{B. Saran}

Penelitian ini memerlukan kajian lebih lanjut dalam hal kondisi reaksi (suhu, perbandingan mol asam dan basa yang digunakan termasuk penambahan katalis) yang dapat menghasilkan borneol sintesis dengan kemurnian dan rendemen yang lebih tinggi.

\section{KONTRIBUSI PENULIS}

Ide, desain, dan rancangan percobaan dilakukan oleh GP, LE, dan TK; percobaan dan perlakuan pengujian dilakukan oleh GP, LE, dan TK; pengumpulan data dan analisis data dilakukan oleh GP, LE, dan TK; penulisan manuskrip oleh GP, LE, dan TK; perbaikan dan finalisasi mansukrip dilakukan oleh GP, LE, dan TK.

\section{DAFTAR PUSTAKA}

Amilia, N., Siadi, K., \& Latifah. (2015). Pengaruh temperatur pada reaksi hidrasi $\alpha$-pinena menjadi $\alpha$ - terpineol terkatalis zeolit alam teraktivasi. Jurnal MIP A, 38(1), 38-48.

Armaka, M., Papanikolaou, E., Sivropoulou, A., \& Arsenakis, M. (1999). Antiviral properties of isoborneol, a potent inhibitor of herpes simplex virus type 1. Antiviral Research, 43, 79-92.

Bao, S., Zhang, D., \& Meng, E. (2019). Improving biosynthetic production of pinene through plasmid recombination elimination and pathway optimization. Plasmid 105,1-7 doi: 10.1016/j.plasmid.2019.102431.

Besari, I., Sulistyowati, E., \& Ishak, M. (1982). Kimia organik untuk universitas. Bandung: Penerbit ARMICO.

Bhatia, S. P., Letizia, C. S., \& Api, A. M. (2008). Fragrance material review on borneol. Food and Chemical Toxicology Journal, 46, 577-580. doi: 10.1016/j.fct.2008.06.031.

Bouzenna, H., Hfaiedh, N., \& Giroux-metges, M. (2017). Science direct potential protective effects of alpha-pinene against cytotoxicity caused by aspirin in the IEC- 6 cells. Biomedicine et Pharmacotherapy, 93, 961-968. doi: 10.1016/j.biopha.2017.06.031.

Cao, B., Ni, H., Li, J., Zhou, Y., Bian, X., Tao, Y., ... Zhu, D. (2017). Biochemical and biophysical research communications (p) -Borneol suppresses conditioned fear recall and anxiety-like behaviors in mice. Biochemical and Biophysical Research Communications, 1-6. doi: 10.1016/j.bbrc.2017.12.025.

Cao, W., Li, Y., Hou, Y., Yang, M., Fu, X., \& Zhao, B. (2019). Biomedicine \& pharmacotherapy enhanced anticancer efficiency of doxorubicin against human glioma by natural borneol through triggering ROS-mediated signal. Biomedicine \& Pharmacotherapy, 118(July), 109261. doi: 10.1016/ j.biopha. 2019.109261.

Chandra, G., \& Murthy, S. S. N. (2018). Dielectric and thermodynamic study of camphor and borneol enantiomers and their binary systems. Thermocbimica Acta, 666(241-252) doi: $10.1016 /$ j.tca.2018.04.014

Daryono, E. D. (2015). Sintesis $\alpha$ - pinene menjadi $\alpha$ -terpineol menggunakan katalis h 2 so 4 dengan variasi suhu reaksi dan volume etanol. Jurnal Teknik Kimia USU, 4(2), 1-6.

Diana \& Budiman, A. (2018). Asetosilasi terpentin Indonesia menggunakan katalis asam sulfat. Teknoin, 24(1), 21-28.

Dong, T., Chen, N., Ma, X., Wang, J., Wen, J., Xie, Q., \& Ma, R. (2018). Biomedicine \& pharmacotherapy the protective roles of $\mathrm{L}$ borneolum, D-borneolum and synthetic borneol in cerebral ischaemia via modulation of the neurovascular unit. Biomedicine \& Pharmacotherapy, 102(January), 874-883. doi: 10.1016/j.biopha.2018.03.087.

Duke, S. (2005). Phytochemical and ethnobotanical databases. Institute for Traditional Medicine. Dalam Plants containing Borneol. Portland, Oregon. National Agriculture Library. US Department of Agriculture.

Fessenden, R. J., \& Fessenden, J. S. (1986). Organic chemistry. (Third Edition). California: 
Wadsworth, Inc.

Frattini, L., Isaacs, M. A., Parlett, C. M. A., Wilson, K., Kyriakou, G., \& Lee, A. F. (2017). Support enhanced alpha pinene isomerization over HPW / SBA-15. "Applied Catalysis B, Environmental,"200, 10-18. doi: 10.1016/i.apcatb.2016.06.064.

Gusmailina. (2015). Review-borneol potensi minyak atsiri masa depan. Prosiding Seminar Nasional Masyarakat Biodiversitas Indonesia, 1(2), 259264. doi://doi org/ 10.13057/psnmbi/ $\mathrm{m} 010215$.

Ho, T., Hung, C., \& Shih, T. (2016). Investigation of borneols sold in Taiwan by chiral gas chromatography. Journal of Food and Drug Analysis, 26(1), 348-352. doi: 10.1016/j.jfda. 2016.10.012.

Ho, T., Hung, C., \& Shih, T. (2018). Investigation of borneols sold in Taiwan by chiral gas chromatography. Journal of Food and Drug Analysis, 26, 348-352. doi: 10.1016 /j.jfda. 2016.10.012.

Hong, L., Li, X., Bao, Y., Duvall, C. L., Zhang, C., Chen, W., \& Peng, C. (2019). Preparation, preliminary pharmacokinetic and brain targeting study of metformin encapsulated $\mathrm{W} / \mathrm{O} / \mathrm{W}$ composite submicron emulsions promoted by borneol Lufeng. European Journal of Pharmaceutical Sciences, 133(160-166) doi: 10.1016/j.ejps.2019.03.019.

Hu, X., Cheng, N., Zhao, J., Piao, X., Yan, Y., Zhang, Q., ... Feng, N. (2019). Percutaneous absorption and brain distribution facilitation of borneol on tetramethylpyrazine in a microemulsion-based transdermal therapeutic system. Asian Journal of Pharmacentical Sciences, 14(3), 305-312. doi: 10. 1016/j.ajps. 2018.06.003.

Jiang, J., Shen, Y. Y., Li, J., Lin, Y. H., Luo, C. X., \& Ya, D. (2015). ( p ) -Borneol alleviates mechanical hyperalgesia in models of chronic in $\mathrm{fl}$ ammatory and neuropathic pain in mice. European Journal of Pharmacology, 757, 53-58. doi: 10.1016/j.ejphar.2015.03.056.

Jin, D., Wang F., \& Qu L. (2011). The distribution and expression of claudin-5 and occludin at the rat blood-optic nerve barrier after borneol treatment. Molecular Biology Report, 38, 913-20. doi: 10.1007/s11033-010-0184-1.

Kim, M., Sowndhararajan, K., Jin, S., \& Kim, S. (2018). Effect of inhalation of isomers, $(+)$ $\alpha$-pinene and $(+)-\beta$-pinene on human electroencephalographic activity according to gender di ff erence. European Journal of
Integrative Medicine, 17(October 2017), 33-39. doi: 10.1016/j.eujim.2017.11.005.

Li, G., Zhao, H., Hong, J., Quan, K., Yuan, Q., \& Wang, X. (2017). Antifungal graphene oxideborneol composite. Colloids and Surfaces B: Biointerfaces. doi: 10.1016/j.colsur fb.2017. 09.023.

Liang, S-y, Zeng, Y-C, Jiang, Q-q, Wu, J-H, \& Wu, Zz. (2020). Pharmacokinetic studies of multibioactive components in rat plasma after oral administration of Xintiantai extract and effects of guide drug borneol on pharmacokinetics. Chinese Herbal Medicines 12(1), 79-87 doi: 10.1016/j.chmed.2019.06. 003.

Liu, Y., Zhao, Y., Guo, D., Liu, W., \& Liu, Y. (2017). Synergistic antimicrobial activity of berberine hydrochloride, baicalein and borneol against Candida albicans. Chinese Herbal Medicines, 9(4), 353-357. doi: 10.1016/S1674-63 84(17) 60115-1.

Lo, K., Jurgita, Š., Pa, A., \& Raudonien, V. (2018). Influence of plant origin natural $\alpha$-pinene with different enantiomeric composition on bacteria, yeasts and fungi. Fitoterapia, 127(February), 20-24. doi: 10. 1016/i.fitote. 2018.04.013.

Madhuri, K., \& Ramachandra, P. (2017). Ameliorative effect of borneol, a natural bycyclic monoterpene against hyperglycemia, hyperlipidemia and oxidative stress in streptozotocin- induced diabetic Wistar rats. Biomedicine \& Pharmacotherapy, 96(August), 336-347. doi: 10.1016/j.biopha. 2017.09. 122.

Masruri, Rahman, M. F., \& Prasosjo, T. I. (2007). Identifikasi dan uji aktivitas antibakteri senyawa volatil terpenoid minyak terpentin. Jurnal Ilmu-Ilmu Hayati (Life Sciences), 19(1), 32-35.

National Institute of Advanced Industrial Science and Technology (AIST), Japan. (2018). Spectral Database for Organic Compounds (SDBS) https://sdbs.db.aist.go.jp/sdbs/cgibin/cre_index.cgi, diakses pada tanggal 15 Juni 2020.

Ndongou, F. J., Selka, A., Fabiano-tixier, A., Foucher, D., Clarisse, O., Chemat, F., \& Touaibia, M. (2018). Highly selective solvent-free hydrogenation of pinenes toadded-valuecispinane. Comptes Rendus - Chimie, 1-8. doi: 10.1016/j.crci.2018.09.002.

Niu, F., Huang, Y., Ji, L., \& Liu, J. (2019). Genomic and transcriptional changes in response to 
pinene tolerance and overproduction in evolved Escherichia coli. Synthetic and Systems Biotechnology, 4(3), 113-119. doi: 10. 1016/j. synbio.2019.05.001.

Pavia, D.L., Kriz, GS., Gary, M., L. (2005). A small scale approach to organic laboratory technique $4^{\text {th }}$ edition. USA: Cengage Learning.

Peng, T. H. X. L. C. (2017). Borneol enhances the antidepressant effects of asiaticoside by promoting its distribution into the brain. Neuroscience Letters. doi: 10.1016/j.neulet. 2017.02.068.

Perum_Perhutani. (2015). Laporan tahunan 2014. Perum Perhutani. Diakses dari http: //www.bumn.go.id/perhutani/halaman/14 8 pada 25 Juni 2020

Perum Perhutani. (2019). Annual report Perum Perhutani 2018. Jakarta.

Ponomarev, D., \& Mettee, H. (2016). Camphor and its industrial s ynthesis. Chemical Education Journal (CEJ), 18(18), 2-5.

Qi, H., Gao, X., Zhang, L., Wei, S., \& Bi, S. (2013). In vitro evaluation of enhancing effect of borneol on transcorneal permeation of compounds with different hydrophilicities and molecular sizes. European Journal of Pharmacology, 705(1-3), 20-25. doi: 10.1016/ j.ejphar.2013.02.031.

Qun-Lin Zhang, Bingmei M. Fu \& Zhang-Jin Zhang. (2017) Borneol, a novel agent that improves central nervous system drug delivery by enhancing blood-brain barrier permeability, Drug Delivery, 24,1, 1037-1044. doi: 10.1080 /10717544.2017.1346002

Ren, J., Hu, C., Zhang, Z., Chen, R., Yang, S., Miao, Z., Wang, Y. (2019). Development and validation an LC-MS/MS method to quantify $(+)$-borneol in rat plasma: Application to a pharmacokinetic study. Journal of Chromatography, B 1109, 121-127 doi: 10.1016 / j.jchromb.2019.01.023.

Ribeiro, C. J. A., Pereira, M. M., Kozhevnikova, E. F., Kozhevnikov, I. V, Gusevskaya, E. V, Kelly, A., \& Rocha, S. (2018). Heteropoly acid catalysts in upgrading of biorenewables:
Synthesis of para - menthenic fragrance compounds from $\alpha$-pinene oxide. Catalysis Today, (May), 0-1. doi: 10.1016/j.cattod. 2018.12.023.

Roma'n-Aguirre, M., Gochi, Y. P., Sanchez, A. R., Torre, L. de la, \& Aguilar-Elguezabal, A. (2008). Synthesis of camphene from a pinene using SO 32 À functionalized MCM41 as catalyst. Synthesis of Camphene from aPinene Using SO3 2 Functionalized MCM-41 as Catalyst, 334, 59-64. doi: 10.1016/ j.apcata. 2007.09.031.

Sánchez-velandia, J. E., Gelves, J., Dorkis, L., Márquez, M., \& Villa, A. (2019). Microporous and mesoporous materials ringopening of $\beta$-pinene epoxide into high-added value products over Colombian natural zeolite. Microporous and Mesoporous Materials, 287(December 2018), 114-123. doi: 10.1016 /j.micromeso.2019.05.053.

Shanghe, C., Meyu, J., \& Xing, H. (2010). Application of B/ Ti-based composite catalyst in synthetic borneol production. Biomass Chemical Engineering, 44(3), 5-8.

Wang, L., Liang, Q., Lin, A., Wu, Y., Min, H., Song, S., Gao, Q. (2019). Borneol alleviates brain injury in sepsis mice by blocking neuronal effect of endotoxin. Life Sciences, 232(March), 116647. doi: 10.1016/j.lfs.2019. 116647.

Wiyono, B., Tachibana, S., \& Tinambunan, D. (2006). Chemical composition of Indonesian Pinus merkusii turpentine oil, gum oleoresins and resins from Sumatra and Java. Pakistan Journal of Biological Sciences, 9(1), 7-14.

Wu, J., Wang, L., Chen, X., Wei, X., Liang, J., \& Yao, G. (2019). Thermochimica acta measurement and correlation of vapor - liquid equilibrium data for binary cymene, and $\alpha$-pinene at $101.33 \mathrm{kPa}$. Thermochimica Acta, 679(June), 178318. doi: 10.1016/j.tca.2019.178318.

Zhang, Q-L., Fu, B.M \& Zhang, Z-J (2017). Borneol, a novel agent that improves central nervous system drug delivery by enhancing bloodbrain barrier permeability. Drug Delivery, 24(1), 1037-1044. doi: 10.1080/10717544. 2017.1346002 . 